\title{
How Political Change Paved the Way for Indigenous Knowledge: The Mackenzie Valley Resource Management Act
}

\author{
JULIA CHRISTENSEN $^{1}$ and MIRIAM GRANT ${ }^{1,2}$
}

\author{
(Received 5 January 2006; accepted in revised form 25 October 2006)
}

\begin{abstract}
This paper highlights the process of political change that led to the Mackenzie Valley Resource Management Act (MVRMA), an attempt to recognize the legitimacy of indigenous knowledge in resource management. Evidence from ethnographic interviews shows the importance of involving indigenous knowledge holders in local land and resource management decisions, which are grounded in land-claim settlement processes. However, the authority of the Indian and Northern Affairs Canada minister acts as a barrier to genuine involvement of indigenous knowledge and its holders in resource management. True capacity building in the Northwest Territories cannot succeed without devolution of power from the federal government to territorial and First Nations governments.
\end{abstract}

Key words: indigenous knowledge, resource management, post-colonialism, land claims

RÉSUMÉ. Cet article porte sur le changement d'ordre politique qui a donné lieu à la Loi sur la gestion des ressources de la vallée du Mackenzie (LGRVM) visant la reconnaissance de la légitimité des connaissances indigènes en matière de gestion des ressources. Des éléments probants découlant d'entrevues ethnographiques attestent de l'importance de faire appel aux indigènes possédant des connaissances en ce qui a trait aux décisions relatives aux terres régionales et à la gestion des ressources qui sont enracinées dans les processus de règlement des revendications territoriales. Cependant, l'autorité du ministre des Affaires indiennes et du Nord canadien constitue un obstacle à la possibilité de faire véritablement appel aux connaissances indigènes et aux personnes possédant ces connaissances en matière de gestion des ressources. Dans les Territoires du Nord-Ouest, l'habilitation véritable ne peut se concrétiser sans la déconcentration du pouvoir du gouvernement fédéral aux gouvernements des territoires et des Premières nations.

Mots clés : connaissances indigènes, gestion des ressources, post-colonialisme, revendications territoriales

Traduit pour la revue Arctic par Nicole Giguère.

\section{INTRODUCTION}

The Mackenzie Valley Resource Management Act (MVRMA) implemented in the Northwest Territories (NWT) in 1998 attempts to recognize the legitimacy of indigenous knowledge formally and to incorporate it into resource management (MVLWB, 1998). In this paper, we explore the processes of political change that culminated in this act. Further, we discuss the ways in which these key political developments localize resource management and thus facilitate shifts toward local participation in resource management decision making. Our qualitative analysis of ethnographic interviews and secondary data provides a foundation for evaluating the extent to which recognition of indigenous knowledge under the MVRMA indicates increasing local control over lands and resources in the Mackenzie Valley. Post-colonial literature lends a theoretical framework to this evaluation and to our discussion of the political and epistemological implications of indigenous knowledge in the MVRMA.

\section{BACKGROUND}

The Mackenzie Valley region of the NWT is a politicallegal division that comprises the majority of the territorial landmass. It includes the Gwich'in and Sahtu settlement areas and the Deh Cho, North Slave, and South Slave areas, but excludes the Inuvialuit settlement area (GNWT, 2003). Three land claims have been settled in the Mackenzie Valley: the Tli Cho (which includes self-government), the Gwich'in, and the Sahtu. Negotiations are still underway for the Akaitcho Territory Dene First Nations, the Deh Cho First Nations, and the Northwest Territory Métis Nation.

Political and social shifts towards greater autonomy through comprehensive land claims and devolution have opened the door to localized approaches to resource management. The MVRMA, implemented in 1998, was the result of settled claims in the Gwich'in (1992) and Sahtu (1993) settlement regions. Its goals were to regulate resource management in the Mackenzie Valley region and to

\footnotetext{
${ }^{1}$ Department of Geography, University of Calgary, 2500 University Dr. NW, Calgary, Alberta T2N 1N4, Canada

${ }^{2}$ Corresponding author: grant@ucalgary.ca

(C) The Arctic Institute of North America
} 
provide northern people with decision-making participation and responsibility in environmental and natural resource matters. The act does this, in part, through its inclusion of indigenous knowledge in the resource management process.

Indigenous knowledge, often referred to as traditional knowledge, refers specifically to "a cumulative body of knowledge, practice, and belief, evolving by adaptive processes and handed down through generations by cultural transmission, about the relationships of living beings (including humans) with one another and with their environment" (Berkes, 1999:8).

The MVRMA was originally conceived along with the Dene-Métis claim. When those claim negotiations fell through in 1990, the intent remained to draft legislation for a Valley-wide resource management act that would shift decision making from the Canadian Environmental Assessment Act to local legislation.

The MVRMA establishes co-management regulatory land and water boards for the Sahtu, Gwich'in, and Tli Cho settlement areas, granting these boards responsibility for issuing land-use permits and water-use licenses. "Comanagement" means that while the federal minister of the Department of Indian and Northern Affairs Canada (INAC) appoints the members of these regulatory boards, half of the members are nominated by First Nations and half are nominated by government. The chairperson, whether a board member or an outsider, is normally nominated by board members themselves, but the INAC minister can overrule and appoint another person if the nominations are not acceptable.

All boards formed under the MVRMA are called "administrative tribunals." They are quasi-judicial bodies and must observe the rules of natural justice in delivering their mandates and be fair and objective in their proceedings and deliberations. Thus, board members must be free of any conflict of interest or apprehension of bias regarding the matters under consideration by the Board.

The Mackenzie Valley Environmental Impact Review Board (MVEIRB), a public body created under the MVRMA as required by land-claim agreements, manages the environmental impact review process in a way that attempts to consider fully both science and indigenous knowledge. Although INAC is no longer deemed to be a regulator under the MVRMA, the federal minister of INAC retains sign-off authority on recommendations from environmental impact review boards.

In Section 115.1 of the MVRMA, the MVEIRB is instructed to "consider any traditional knowledge and scientific information that is made available to it." Furthermore, the Board makes its own commitment to the recognition of indigenous knowledge, asserting that "In order to ensure that aboriginal cultures, values and knowledge play an appropriate role in its determinations, the Review Board is committed to fully consider any traditional knowledge brought forward in its proceedings" (MVEIRB, 2005:4).
All comprehensive land-claim agreements in the NWT call for direct involvement of Aboriginal beneficiaries in the management of wildlife and resources. This means that all environmental impact reviews require the consideration of indigenous knowledge through the input and participation of local indigenous knowledge holders, which marks a significant shift in the politics of knowledge at work in the NWT.

\section{METHODS}

We used qualitative methods to explore the political and social changes in the NWT that have led to the incorporation of indigenous knowledge in resource management. From June to August 2004, we conducted indepth, semi-structured interviews with 25 expert informants and key stakeholders in Yellowknife, NWT. Our informants included representatives of territorial, aboriginal, and federal governments, as well as Northerners active in land claims or self-government movements. All had professional or personal connections (or both) to the application of indigenous knowledge in resource management in the NWT, and all were knowledgeable about and involved in past and current political developments in the North. We also collected and analyzed extensive secondary data from archives, media reports, and government documents.

\section{CONSIDERING (POST-) COLONIALISM IN THE NWT}

Post-colonialism is a political and intellectual approach that critiques the impact of colonialism and the reproduction of colonial relations, practices, and representations in the present (Gregory, 2000). While suggesting that the NWT be regarded as a post-colonial space is neither the purpose nor the intent of this paper, we are interested in using this framework to explore the significance of the political changes that led to the creation of the MVRMA and subsequently to the inclusion of indigenous knowledge in resource management.

The relationship between indigenous peoples and the federal government in Canada has been described as one of internal colonialism (Sidaway, 2000; Bone, 2003). In the NWT, the territory's history as a "ward" of INAC and a place to extract resources for the rest of Canada-and especially the colonial experience of local indigenous peoples-have served to create the common perception of a colonial relationship with the federal government. This perception persists in local political, media, and everyday social discourse and was expressed repeatedly by our interview respondents.

The significance of the recognition and appreciation of indigenous knowledge in this context is great. If a colonial-type relationship is perceived, then what does the inclusion of indigenous knowledge in resource management mean? What does it say about power dynamics in the 
North? Recognition of indigenous knowledge in this context is especially potent because knowledge lies at the core of the colonizing process and the colonizing identity, just as it lies at the core of the indigenous cultural identity. Land and knowledge are both sites of struggle at the very root of colonialism.

The assertion of an intimate knowledge of the land, accumulated through generations of lived experience, has given Aboriginal people the leverage to demand greater participation in resource management. Formal inclusion of indigenous knowledge in resource management serves to recognize an indigenous claim to space. It is especially significant because it implies shifting control of the social production of space and effectively asserts a right to representation and participation in decision making for resource management.

According to Berkes (1999:164), "indigenous knowledge is political because it threatens to change power relations between indigenous groups and the dominant society." In other words, indigenous knowledge threatens to shift the balance of power between indigenous groups on the one hand, and governments, developers, and conventional resource-management scientists on the other. Such assertion of indigenous knowledge is not merely a cultural exercise; it is about empowerment and political control (Berkes, 1999).

If colonialism involves "dominance over a separate group of people, who are viewed as subordinate, and their territories, which are presumed to be available for exploitation" (Said, 1993:8), then post-colonialism also takes on space - and therefore, territory - as a key point of concern. Land, in this sense, becomes a playing field on which the politics of knowledge and power dynamics enact themselves in both colonial and post-colonial contexts.

How did political change in the NWT lead to the creation of the MVRMA? How has this change opened spaces of inclusion for indigenous knowledge in resource management? Did political momentum cultivate a political climate that emphasized the need for indigenous knowledge in resource management? In the following sections, we discuss these developments in turn and explore how the politics of knowledge affects the increasing capacity of local people to make decisions about resource management in the NWT.

\section{RESULTS}

Interview respondents outline a series of political developments that they identify as critical to the creation of the MVRMA and to opening spaces for the inclusion of indigenous knowledge in the resource management process. Furthermore, respondents maintain that the inclusion of indigenous knowledge indicates increasing local decision-making capacity in resource management. All quotations from respondents in the following sections are excerpted from transcripts of interviews held in Yellowknife between 1 June and 15 August 2004.

\section{Political Development and Mobilization}

The NWT has long been the site of constant social and political change. However, since the 1967 transfer of the territorial government from Ottawa to Yellowknife, the degree of change has been especially significant. The atmosphere of political change in the NWT has provided the context for a dramatic shift in power dynamics in the North in a relatively short time.

Until 1966, the territorial council that governed the NWT was based in Ottawa, and the majority of its members were appointed by the federal government. In that year, upon recommendation of the Carrothers Commission, responsible government was returned to the NWT, with Yellowknife as capital, a majority of elected members in the territorial council, and Stuart Hodgson as federally appointed Commissioner. By 1970, only four federal appointees remained in the 14-person territorial assembly.

Our respondents regard the relocation of the territorial government from Ottawa to Yellowknife as a highly symbolic event in the political development of the NWT and as the starting point for the long process of devolution of responsibilities from the federal to the territorial government. They view the first fully elected territorial council in 1975 as the second significant milestone along a continuum of increasing local control over political development.

The 1970s also set the stage for a growing Aboriginal political consciousness, which in turn fuelled the development of territorial political autonomy. A majority Aboriginal population meant that movements of self-determination had a significant political impact on the territory as a whole. The NWT-based Indian Brotherhood (now the Dene Nation) and the Métis and Non-Status Indian Association (Métis Nation) were formed in 1970. Motivated by growing territorial political autonomy, Aboriginal peoples began to assert themselves as distinct peoples, with rights inherent in their indigenous identity. Cultural politics allowed Aboriginal people to take command at the local scale by virtue of their indigenous status. By asserting an indigenous identity, they laid claim to a place, an intimate, local experience of knowing the landscape and everything held within it (Nuttall, 1998; Brown and Purcell, 2002).

The political mobilization of Aboriginal people seemed to emerge from increased autonomy at the territorial level, and the combined momentum created synergy. Together, Aboriginal and non-Aboriginal Northerners alike called for greater control over their affairs and increased recognition of the unique culture and identity of the North. Northern people wanted autonomy and ownership over decisions affecting local communities, local lands, and local resources. This call for self-determination was expressed on the widest-reaching scale during the Mackenzie Valley Pipeline Inquiry.

\section{The Mackenzie Valley Pipeline Inquiry}

The Mackenzie Valley Pipeline Inquiry, commonly known as the Berger Inquiry, lent credibility to local 
knowledge and management traditions, brought the push for land claims to the attention of the Canadian public, and contributed to the development of an Aboriginal rights movement (Zachariah, 1984). The inquiry board was appointed in the mid-1970s to consider issues surrounding the social, environmental, and economic impact of a proposed gas pipeline across the northern Yukon and through the Mackenzie Valley (Berger, 1988). However, the inquiry "was more than an investigation into a single project; it was an examination of the purpose of northern development, the place of the environment in Canadian society, and the potential role of northern peoples in that development" (Bone, 2003:169). The Berger Inquiry took place at a time when Aboriginal groups were organizing themselves politically to assert the uniqueness of their ethnic and cultural identities, as well as their right to self-government and control over local territories, through comprehensive land claims.

The tension between opposing views of the North was central to the conflict discussed in Justice Berger's (1988) report, Northern Frontier, Northern Homeland. At the time, most Canadians regarded the North as a hinterland with substantial economic potential. The Berger Inquiry, then, was not "simply a debate about a gas pipeline and an energy corridor, it [was] a debate about the future of the North and its peoples" (Berger, 1988:31). It was a significant turning point in the evolution from colonial to postcolonial status: opposing concepts of the North came face to face in contestation over land.

Aboriginal groups resisted notions of the North as a "frontier" or "wilderness," calling instead for "recognition of Arctic lands as indigenous homelands" (Nuttall, 1998:87). Here, an image of the North as a natural resource is challenged by the people's image of their local experience of the landscape through notions of ancestry, history and, most of all, home.

Dene leaders believed that their people needed a landclaim settlement before they could truly benefit from megaprojects such as the Mackenzie Valley Pipeline. Strong opposition from Aboriginal peoples during the inquiry posed a major stumbling block for that pipeline proposal (Bone, 2003:155). The prevailing feeling from the rest of Canada was that stalling the pipeline until land claims were settled would give Aboriginal people "the means, in a phrase popular at the time, 'to hold the country to ransom.' It was a contest between two cultures, between two quite distinct ideas of progress for the North" (Berger, 1988:5-6).

Our respondents spoke with intense enthusiasm about the past and present impacts of the Berger Inquiry on northern political affairs. Its proceedings and final report were of great interest to the Canadian public at large and reshaped common attitudes towards industrial development, the environment, and Aboriginal issues. Berger drew the public's attention to the environment and culture of Aboriginal peoples and provided the space for local Aboriginal people to articulate their views on land claims and other issues directly to the nation as a whole, by communicating their own beliefs, values, and experience with respect to local lands and resources. Since Aboriginal groups insisted that no pipeline be built through the Mackenzie Valley until comprehensive land claims were settled, Berger's acknowledgement of Aboriginal rights served to shape the future of the North and its spatial and political conception.

The Berger Inquiry was the initial impetus for today's incorporation of indigenous knowledge into resource management because it set a precedent of consultation with local people. "It's just part of the same thing, listening to people, consulting them. Traditional knowledge happens to be one of the things that people have," says John T'Seleie, born and raised in Fort Good Hope, NWT, who was involved with the Indian Brotherhood during the Berger Inquiry. He adds: "I think the Berger Inquiry had a lot to do with [the level of consultation today]." The inquiry, says Kris Johnson, Lands and Resources Manager with the North Slave Métis Alliance, "really opened a lot of people's eyes to what people here wanted and needed in order for a project like that to go through."

Furthermore, the Berger Inquiry facilitated the unity of the Dene people and helped them to express their identity on both national and international scales. The inquiry also demonstrated to Aboriginal people that they could use the Canadian political system to assert their demands (G. White, pers. comm. 2005).

Gabrielle Mackenzie-Scott, a member of MVEIRB who was born and raised in Rae, NWT, explains that by providing a space for local indigenous people to voice their perspectives, the inquiry led to the increased voice they have today: "We wanted to be recognized as Dene nationally and internationally... For our unity, it was important to tell people, to show people, who we are. There was a lot of exciting change. People have more say now."

Stephen Kakfwi, a member of the NWT Legislature for 16 years, represented the Sahtu constituency and then served as premier from 2000 to 2003. During the Berger Inquiry, as a member of the Indian Brotherhood, Kakfwi advocated against the Mackenzie Valley Pipeline development. At the time of the inquiry, he says, indigenous peoples had no political presence or knowledge of how to participate within the political system: "We were just not part of Canada as most Canadians know it....Even if we were invited, we couldn't be part of it because we had no way to benefit" (CBC, 2003). Political inclusion was sought largely through the assertion of comprehensive land claims, representation in local government, and participation in the wage economy:

For the past 25 years, we've worked to become part of the Government of the NWT. We are present in the civil service. We are present in Ottawa as members of parliament and senators. We are economically active and many of our people are business people... So we are now the ones who actually proposed the pipeline in January of 2000. Most of 
us who proposed it, we are ones who fought to defeat it in the seventies. (CBC, 2003)

Indeed, those who led the opposition to the pipeline in the 1970s are now among its most enthusiastic supporters. What has changed, Kakfwi says, is the presence of Aboriginal people in the system. Through their work to settle land-claim agreements and to become members of territorial and federal governments and the public and private sectors, Aboriginal people in the NWT today are not only poised to benefit from development: they are poised to direct it. This strong Aboriginal political presence, along with the greater autonomy of the territorial government, has created a context of political change that facilitates an increase in the decision-making capacity of northern people in resource management.

\section{Comprehensive Land-Claim Agreements}

The Berger Inquiry furthered pressure for the settlement of land claims, which led the federal government to adopt a comprehensive policy on land claims in 1976. The land-claim movement signifies a renewed determination and a new capacity on the part of Aboriginal peoples in the North to defend what they believe to be their right to make their own future (Berger, 1988).

Comprehensive land claims recognize continuing Aboriginal rights to lands and natural resources and include land title and fishing and trapping rights, as well as financial compensation. Like historic treaties, comprehensive land claims establish "principles for land ownership and use and for political-governmental relations between Aboriginal peoples and the Canadian state" (White, 2002:93).

The patriation of the Canadian Constitution in 1982 entrenched Aboriginal and treaty rights and also recognized that "treaty rights" included those already in existence and those that might be acquired through land-claim agreements. At that time, several land claims by NWT Aboriginal groups were making their way through the courts and the federal government. The first comprehensive land claim in the NWT was settled in 1984, with the Inuvialuit Final Agreement.

Although an agreement-in-principle with the government of Canada was reached on a joint Dene-Métis land claim in 1990, this agreement failed when some of the bands did not support it. Two Dene-Métis organizations reached separate land-claim agreements: the Gwich'in Tribal Council in 1992 and the Sahtu Tribal Council in 1993. The Tli Cho Lands, Resources, and Self-Government Agreement was approved by Parliament in 2005. Other claims in the Deh Cho, North Slave, and South Slave regions remain in negotiation.

The comprehensive land-claim process has contributed significantly to increasing local autonomy in the NWT. Since Aboriginal people now have access to, and ownership in, the system, local indigenous people are more involved in the resource management process and have greater control over it. The comprehensive land-claim process has subsequently acted as a platform for other political developments, such as the MVRMA and selfgovernment negotiations.

Land-claim settlements and the stipulations for local consultation have been particularly important in light of recent surges in diamond mining and oil and gas development. Industries must communicate with affected communities and other stakeholders and have therefore set the legal structure necessary for Aboriginal peoples to have more say in decisions affecting traditional territory.

In this way, land claims have effectively contributed to a shift of power toward the local level. As local control increases, the mechanisms that local people deem appropriate to manage local lands are given greater attention and are in greater use. This, in turn, has brought about the increased incorporation of indigenous knowledge. The reacquisition of land through land claims has brought with it the reacquisition of the right to decide what is done to the land.

Drawing on the experience of the Tli Cho people, Gabrielle Mackenzie-Scott states that their land claim has given them a say in the way their communities, lands, and resources are managed: "These days, we feel like we have a say," she says. "Our land claim does have a lot to do with that."

Land claims are symbolic in their recognition of Aboriginal groups' inherent right to traditional territory, so they serve to stimulate self-determination and cultural awareness. Furthermore, land claims act as political platforms from which to assert an even greater say over political, economic, social, and resource management issues.

However, the comprehensive land-claim process is also subject to criticism. An anonymous interview participant indicated that Aboriginal groups are given no choice but to participate in the negotiation process. Moreover, that participant asserted, instead of the return of the entirety of their traditional territory, Aboriginal groups are given small fractions of their former lands and are made to feel as though they are fortunate to receive anything at all. Another anonymous respondent criticized the process for simply perpetuating a colonial relationship between the federal government and Aboriginal groups, arguing that doling out small pockets of land is an insult and does nothing to right the wrongs of the Canadian past.

Despite these criticisms, however, respondents perceived a critical disparity between Aboriginal groups with a settled claim and those without one, which fuels persistence to achieve a settlement. Aboriginal groups without a settled land claim have less say in development than those with a settled claim. Interview participants felt that while the process of negotiating land claims is complex and, at times, very frustrating, in the end, a settled land claim strengthens the First Nation's position. Kris Johnson maintains that the North Slave Métis do not have an adequate say in development because they lack a settled land claim. With a settled land claim, she says, "we could start doing things like land-use planning and protected areas more than we can now." 
Land claims have cultivated a general sense of autonomy and responsibility for the future of the North within the greater NWT population and therefore play a significant role in increasing the ability of local people to participate in local resource management. In particular, land claims laid the groundwork for the MVRMA, which in turn aims to provide a legal foundation for increasing local decision making.

\section{Mackenzie Valley Resource Management Act (MVRMA)}

Interview participants recognize the MVRMA as the direct result of settled land claims in the Mackenzie Valley and identify it as the culmination of a series of political changes that have brought greater decision-making capacity to the local level. The MVRMA has built upon the political mobilization of Aboriginal peoples and the increasing autonomy of the territorial and Aboriginal governments. The act aims to give local people a greater role in managing lands and water and protecting the environment in the Mackenzie Valley.

Archaeologist Tom Andrews, a longtime NWT resident, says the MVRMA has emerged from the collective struggle of the Dene Nation and other Aboriginal organizations since the 1970 s to bring attention to themselves as equal players and partners in northern development and in knowledge.

Timing also played a key role in ensuring the inclusion of indigenous knowledge in the MVRMA, adds Charles Arnold, another archaeologist who has spent much of his life in the North. The act emerged, he says, at a time when recognition of the importance of traditional knowledge in land-use decision making was building. Furthermore, emerging Aboriginal political organizations participated in developing the act, which helped drafters include traditional knowledge as a requirement.

John B. Zoe, born and raised in Rae, NWT, served as land claims and self-government negotiator for the Tli Cho Agreement. He believes that the recognition of indigenous knowledge is changing the way things are done in the Mackenzie Valley:

In the past, the people's advice wasn't being sought. Meetings were about telling people what to do. Now, it's a matter of letting people have a say. I mean, they are the only people in the world with an intimate knowledge of the land - their knowledge of the land is based on survival and knowing how to survive on the land, and it's a lot more knowledge than people from the outside [have].

There is significant criticism of the MVRMA, however. The boards formed under the act are not decision-making bodies: they can only make recommendations, and this limitation fuels some uncertainty and skepticism. In theory, the Minister of INAC holds ultimate decision-making authority. However, respondents who represent the MVEIRB insist that in practice, it is very difficult for the minister to ignore the board's recommendations. White
(2006:402) also finds that while the federal government can and does reject board decisions, it does so rarely. In fact, he asserts, "boards wield considerable decisionmaking clout." Nevertheless, many respondents perceive the INAC minister as unwilling to relinquish control. They argue that the minister's final authority limits the northern peoples' sense that they own the decision-making process and has undeniable implications for the power relations in the Mackenzie Valley.

The MVRMA is also criticized for being imposed on groups without settled land claims. While the act resulted from settled land claims for the Sahtu and Gwich'in, some groups with unsettled land claims, such as the Deh Cho and Akaitcho, have resisted inclusion in the MVRMA and instead call for their own separate, regional resource management agreements. These groups feel they were not adequately consulted in the drafting of the legislation and have since been forced into the MVRMA as a legislated arrangement. Respondents involved in the drafting of the MVRMA also expressed concern that the legislation was laid out before all claims were settled and before further devolution of power. Aboriginal groups without settled claims were not given the same kind of decision-making power in the drafting process as those groups with settled claims.

Co-management itself has also received frequent criticism. The primary question is whether co-management boards can "incorporate" and "apply" indigenous knowledge meaningfully and effectively within a system created by the institutions and practices of scientific resource management itself (Nadasdy, 1999). Further, both Nadasdy (1999) and White (2005) argue that fundamental incompatibilities between Aboriginal values, practices, and beliefs and the conceptual framework of the scientific resource management system present a real barrier to infusing boards with Aboriginal values. Instead, indigenous knowledge is used merely as supplementary data, taken out of context, and reduced to numbers and statistics (Nadasdy calls these "artifacts") that are compatible with the scientific resource management paradigm (Stevenson, 1996). Effective and meaningful improvement of management and increased local empowerment require that "local beliefs, values, and practices themselves - not merely the abstract forms affixed to them-be accepted as a valid basis for action" (Nadasdy, 1999:13).

The epistemological and political dimensions of trying to give equal consideration to both indigenous knowledge and Western science in resource management indeed warrant further discussion. Our respondents also acknowledged that for scientists to consult effectively with traditional knowledge holders in the resource management process, more work is needed. However, interview respondents were more concerned that co-management arrangements give local Aboriginal people greater representation and participation in the process, so that their knowledge would be contributed to decision making on resource management. For respondents, the issue was not 
so much how to integrate two different "ways of knowing": it was to ensure that decisions would no longer be made for the people, but rather by the people.

Although Nadasdy's (1999) critique holds a great deal of weight, it is important not to underestimate the capacity of local people to work within the process to achieve their goal of greater decision-making capacity. Furthermore, it is a mistake to ignore the significant gains that the landclaim and co-management processes represent for Aboriginal people in the North (White, 2006). Interview participants regard the MVRMA and the valley-wide legislation it imposes as a move towards greater decisionmaking capacity for local people. The critical issue, they say, is not so much the incorporation of indigenous knowledge as a component in the overall resource management system, but rather the involvement of indigenous knowledge holders in all stages of that process. Knowledge, they reiterate, is not a stand-alone element, and the holders of knowledge must be engaged in the resource management process in ways that are truly meaningful to them.

\section{DISCUSSION}

Land is at the crux of this inquiry, which encompasses notions of land, attachment to land, ownership and control of land, and the central role land plays in political power. Land is a significant site of contestation around which, and on which, shifting power dynamics play out, and it is at the centre of the politics of knowledge. The relationship between land and power is particularly significant within a post-colonial inquiry, since the acquisition and dominance of land-and of the people therein-is a central aim of colonialism. A colonial power acquires supremacy by imposing its own systems and values upon the lands of others.

Political developments, such as comprehensive land claims and devolution, shift ownership and control of land to local people. Alongside the reacquisition of land by local people has come the assertion that in land and resource management, indigenous knowledge is not only valuable, but necessary. Post-colonial theory is particularly interested in the complicity between power and knowledge. As Berkes (1999) suggests, efforts to incorporate indigenous knowledge are political in that they unsettle power relations between Aboriginal peoples and the dominant society in Canada. With this shift in power towards the local, then, we see a corresponding shift in the forms of knowledge deemed legitimate in local resource management.

The key political developments that respondents identify as culminating in the MVRMA and its consideration of indigenous knowledge in resource management have helped to reorganize the spatial and political composition of the North. They have led to shifting power dynamics that not only welcome the inclusion of indigenous knowledge, but insist upon it.

Assigning the territorial government headquarters to Yellowknife brought the political process home, enabling both a sense of local ownership over the political process and an involvement in the larger Canadian political arena. A fully elected territorial council, with a membership that reflected the strong indigenous presence in the NWT, intensified that sense of ownership.

The paradigm shift that began to occur over this time was sparked by these autonomy-fuelling political events, and at the same time, created momentum for further political mobilization. Northerners were becoming more organized and more assertive in their demands. The federal government began to recognize that the political arrangement needed to change in order to appease northern peoples in their demands for greater authority.

Occurring in tandem was the rise of Aboriginal political organization that, in turn, helped to fuel the larger northern autonomy movement. Aboriginal activism effectively attached a distinct, northern indigenous identity to demands for increased northern autonomy. Nuttall (1998) suggests that connecting the autonomy movement to an indigenous identity strengthened its political clout by asserting a distinct cultural, ethnic connection to "place." Asserting the uniqueness of northern life justified the insistence that the future of Canada's North would be best directed by Northerners.

The Berger Inquiry provided a timely venue in which Northerners could express their aspirations to the rest of the country and an excellent forum for asserting their indigenous identity, as well as their cultural and ethnic attachment to the northern landscape. The significance of the Berger Inquiry for the political development of the NWT is profound. With its recommendations, the inquiry provided critical justification for the settlement of land claims and lent credibility and recognition to indigenous knowledge, and it is regarded as the initial impetus behind today's formal efforts to incorporate indigenous knowledge into resource management. The inquiry set in motion the political evolution that has increased the say of local people in decision making for resource management today.

Prior to the Berger Inquiry, Elias (1991:22) writes, history had plodded along a course of exploitation of the North's resources, perpetuating a "metropolis-hinterland" relationship, which resulted in the impoverishment of the North for the enrichment of the South. As Elias puts it, "Berger's recommendations changed this course of history."

The recognition of Aboriginal rights over this time period has marked a major shift in Canadian policy. Progress, once measured by the proportion of Aboriginal people who abandoned "old ways," is now seen in terms of measures to preserve Aboriginal cultures "and to reassume the rights and obligations that had been set aside" (Armitage, 1999:66).

Land claims have given Aboriginal peoples a claim in Canada-a claim to Canada. Further, land claims have given Aboriginal peoples presence in the Canadian system and positioned them not only to benefit economically from development, but to influence its course. Land claims can act as political platforms from which to assert an even 
greater say over political, social, economic, and resource management issues.

Aboriginal claims to land, resources, sovereignty, selfgovernance, and knowledge disrupt the organized mechanisms that homogenize Canada spatially and politically, and they defy its colonial heritage. In this way, comprehensive land claims unsettle colonial claims to space (and therefore, to power) by asserting indigenous land rights.

Colonialism is centrally concerned with acquiring territory, so the reacquisition of that territory by its original inhabitants is highly significant_-as are the corresponding shifts in the forms of knowledge applied to managing that land. Reacquisition of land leads not only to greater control, but also to freedom to conceive of, and organize, that land, which has brought increased recognition of the need to include indigenous knowledge. It is through these spatial strategies made possible by land claims that interview participants perceive a gain in control over decision making for resource management at the local level.

Land claims are clearly symbolic in their reorganization of the territorial map and political landscape. Moreover, they have increased the authority and decision-making capacity of Aboriginal groups (Usher, 1993; Ironside, 2000). Yet while there are many ways to analyze land claims from a post-colonial perspective, there are also colonial underpinnings to land claims that we must not ignore. The land-claim process is in some ways a forced compromise for Aboriginal groups, since the outcome is limited before negotiation even begins.

However, in the emerging context of unprecedented resource development in the NWT, land claims have become very powerful instruments. A product of colonial origin has been used to achieve very post-colonial aims. Land claims have proved significant in increasing local say and decisionmaking capacity, as shown by the disparity in authority between groups with settled claims and those without. Respondents identified land claims as the means by which Aboriginal peoples have acquired greater authority and decision-making capacity in the NWT. Furthermore, land claims in the NWT were perceived as a major contributor to an overall increase in autonomy and authority for indigenous and non-indigenous Northerners alike.

\section{CONCLUSION}

By legislating the inclusion of indigenous knowledge in resource management, the MVRMA recognizes both Aboriginal land rights and the basis for those rights. However, fully recognizing the basis for Aboriginal land rights requires that more be done to imbue the resource management process with Aboriginal values and beliefs. What is necessary is recognition of the generations upon generations of intimate knowledge of and experience on the land from which those rights derive. To truly recognize this means making a paradigm shift—or as John Zoe put it, "speaking a different language" - that embraces, values, and legitimizes the knowledge and values of Aboriginal peoples.

Yet as White (2005) and Nadasdy (1999) observe, a resource management process that is rooted in a EuroCanadian tradition remains a firm barrier to fully realizing this paradigm shift. When abstracted from the culture of which it is a part, indigenous knowledge might be distilled and reduced to "artifacts" to make it compatible with the bureaucratic functions and processes of modern resource management (Agrawal, 1995a; Nadasdy, 1999; Stevenson, 1996). Knowledge is bound up in the contingencies of space and time. Indigenous knowledge is, therefore, firmly rooted in the lived landscape, along with the values, practices, and beliefs of the people that produce it. If resource management is truly going to consider and apply indigenous knowledge, then the management process itself must embody those same values, practices, and beliefs.

However, the issue for respondents remains first and foremost the participation of local people in the resource management process. Respondents felt that attempts to involve indigenous knowledge holders meaningfully in such decision making were critical. Therefore, if an indigenous knowledge policy is not about listening to the people and furthering their decision-making capacity, it will not be meaningful to indigenous people.

Respondents cited the creation and implementation of the MVRMA as contributing to an increase in local decision making for resource management. The structure of the MVRMA, the co-management boards it establishes, the legitimacy it affords indigenous knowledge, and the fact that its roots lie in land claims all serve to localize decision making for resource management in the Mackenzie Valley.

However, despite all of this, the authority of the INAC minister poses some critical barriers to the meaningful involvement of indigenous knowledge and indigenous knowledge holders in the resource management process by "tokenizing" local input.

There are indeed post-colonial trends in the current political development of the NWT. Undoubtedly, much has changed in the past three decades. The significance of incorporating indigenous knowledge in resource management cannot be underestimated. It serves as a definite indicator of shifting power dynamics in the NWT and the cultivation of greater local capacity for decision making. However, local decisionmaking capacity in the NWT increases only to a certain degree, at which point it is effectively stifled by the persistent authority of the federal government. For true capacity building in the NWT, the federal government must effectively devolve authority to both territorial and First Nations governments. Northern people need to be in control of their future and that of their lands and their communities.

\section{ACKNOWLEDGEMENTS}

Our heartfelt thanks to the many people who participated in this research as interview respondents. Your time, energy and thoughtful 
insight were invaluable. Thank you also to the Northern Scientific Training Program (NSTP), which provided funding for field research, and to the reviewers for their helpful advice and comments.

\section{REFERENCES}

AGRAWAL, A. 1995. Dismantling the divide between indigenous and scientific knowledge. Development and Change 26: 413-439.

ARMITAGE, A. 1999. Comparing Aboriginal policies: The colonial legacy. In: Hylton, J.H., ed. Aboriginal self-government in Canada. Saskatoon: Purich Publishing Ltd. 61-77.

BERGER, T.R. 1988. Northern frontier, northern homeland. Vancouver: Douglas and McIntyre.

BERKES, F. 1999. Sacred ecology: Traditional ecological knowledge and resource management. Philadelphia: Taylor and Francis.

BONE, R.M. 2003. The geography of the Canadian North. Oxford: Oxford University Press.

BROWN, J.C., and PURCELL, M. 2002. Rescaling political ecology: The scalar politics of development in the Brazilian Amazon. Paper presented at the annual meeting of the Association of American Geographers, 22 March 2002, Los Angeles, California.

CANADIAN BROADCASTING CORPORATION. 2003. CBC Radio Special Report: Interview with Steve Kakfwi. September 30, 2003, 6:45 am.

ELIAS, P.D. 1991. Development of Aboriginal people's communities. North York: Captus Press.

GNWT (GOVERNMENT OF THE NORTHWEST TERRITORIES). 2003. Northwest Territories boundaries map. Yellowknife: Ministry of Aboriginal Affairs. http:// www.enr.gov.nt.ca/maps/index.htm.
GREGORY, D. 2000. Post-colonialism. In: Johnston, R.J., Gregory, D., Pratt, G., and Watts, M., eds. The dictionary of human geography. Oxford: Blackwell.

IRONSIDE, R.G. 2000. Canadian northern settlements: Top-down and bottom-up influences. Geografiska Annaler 82(2): $103-114$.

MVEIRB (MACKENZIE VALLEY ENVIRONMENTAL IMPACT REVIEW BOARD). 2005. Guidelines for incorporating traditional knowledge in environmental impact assessment. http://www.mveirb.nt.ca/reference_lib/guidelines.php.

MVLWB (MACKENZIE VALLEY LAND AND WATER BOARD). 1998. The Mackenzie Valley Resource Management Act. http://mvlwb.com/doc/mvrma.pdf.

NADASDY, P. 1999. Politics of TEK: Power and the "integration" of knowledge. Arctic Anthropology 36(1-2):1-18.

NUTTALL, M. 1998. Protecting the Arctic: Indigenous peoples and cultural survival. The Netherlands: Harwood Academic Publishers.

SAID, E. 1993. Culture and imperialism. London: Vintage Books. SIDAWAY, J.D. 2000. Postcolonial geographies: An exploratory essay. Progress in Human Geography 24(4):591-612.

STEVENSON, M.G. 1996. Indigenous knowledge in environmental assessment. Arctic 49(3):278-291.

USHER, P.J. 1993. Northern development, impact assessment, and social change. In: Dyck, J.B., ed. Anthropology, public policy and Native peoples in Canada. Montreal: McGill University Press. 98-130.

WHITE, G. 2002. Treaty federalism in northern Canada: Aboriginal government lands claims boards. Publius: The Journal of Federalism 32(3):89-114.

. 2006. Cultures in collision: Traditional knowledge and Euro-Canadian governance processes in northern land-claim boards. Arctic 59(4):401-414.

ZACHARIAH, M. 1984. The Berger Commission Inquiry and the revitalization of indigenous cultures. Canadian Journal of Development Studies 5:65-77. 